\title{
Assessing the biodegradability of terrestrially-derived organic matter in Scottish sea loch sediments
}

\author{
P. S. Loh ${ }^{1, *}$, A. E. J. Miller ${ }^{2}$, A. D. Reeves ${ }^{3}$, S. M. Harvey ${ }^{2}$, and J. Overnell ${ }^{2}$ \\ ${ }^{1}$ UHI Millennium Inst., Scottish Association for Marine Science, Dunstaffnage Marine Lab., Oban PA37 1QA, Scotland, UK \\ ${ }^{2}$ Scottish Association for Marine Science, Dunstaffnage Marine Laboratory, Oban PA37 1QA, Scotland, UK \\ ${ }^{3}$ Environmental Systems Research Group, Geography Department, University of Dundee, Dundee DD1 4HN, Scotland, UK \\ * present address: Institute of Marine Geology and Chemistry, National Sun Yat-Sen University, Kaohsiung, Taiwan
}

Received: 22 October 2007 - Published in Hydrol. Earth Syst. Sci. Discuss.: 6 November 2007

Revised: 4 April 2008 - Accepted: 7 May 2008 - Published: 26 May 2008

\begin{abstract}
Lignin oxidation products, oxygen uptake rates, molar organic carbon to nitrogen $(\mathrm{OC} / \mathrm{N})$ ratio (from bulk elemental analysis) and $R p$ values (from loss on ignition experiments, the ratio of the refractory to total organic matter, OM) were determined for sediments along transects of Loch Creran and Loch Etive. Lignin data indicated the importance of riverine inputs contributing to land-derived carbon in the lochs as total lignin $(\Lambda, \mathrm{mg} / 100 \mathrm{mg}$ organic carbon, OC) decreased from 0.69 to 0.45 and 0.70 to 0.29 from the head to outside of Loch Creran and Loch Etive, respectively. In addition, significant correlations of lignin content against total OM and OC $(p<0.05)$ also suggested a distinct contribution of terrestrial OM to carbon pools in the lochs. The general trend of decreasing oxygen uptake rates from the head $\left(20.8\right.$ mmole m$^{-2}$ day $\left.^{-1}\right)$ to mouth $\left(9.4\right.$ mmole m$^{-2}$ day $\left.^{-1}\right)$ of Loch Creran indicates decomposition of OM. Biodegradability of the sedimentary OM was also characterized by the increase of $R p$ values from the head to mouth of the lochs: 0.40 to 0.80 in Loch Etive and 0.43 to 0.63 in Loch Creran. Furthermore, the molar OC/N ratio decreased from 11.2 to 6.4 in Loch Creran, and from 17.5 to 8.2 in Loch Etive. Derived rate constants for $\mathrm{OM}$ degradation were found to decrease from LC0 to LC1, and increase from RE5 to RE6. This work demonstrates that oxygen uptake rates, $R p$ values and molar $\mathrm{OC} / \mathrm{N}$ ratio are able to serve as useful proxies to indicate the biodegradability of sedimentary OM.
\end{abstract}

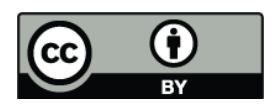

Correspondence to: P. S. Loh

(psloh@staff.nsysu.edu.tw)

\section{Introduction}

The meaning of biodegradation is the biologically catalysed reduction in the complexity of chemicals and usually results in conversion of organic carbon (OC), nitrogen (ON), phosphorus and sulphur to inorganic products (Alexander, 1999). Hence, "biodegradability" refers to the susceptibility of the organic matter (OM) to degradation; or to the "freshness" or "quality" or "diagenetic state" of OM. Early attempts to determine biodegradability were carried out by Westrich and Berner (1984), who studied oxygen uptake rates in laboratory incubated sediments. Studies have since used the oxygen uptake rate in intact incubated sediment cores, as this represents the amount of OM directly oxidised during aerobic degradation (Parsons et al., 1977; Henrichs, 1992; Overnell et al., 1995). Others have used oxygen uptake rate as a measure of OM mineralization through an aerobic pathway, the oxygen being supplied by the activity of burrowing organisms (Wassman, 1984; Grant and Hargrave, 1987; Glud et al., 1994). However, there are some shortcomings of this approach. The oxygen uptake could also be due to the oxidation of reduced species formed during anaerobic OM degradation (Elsgaard and Jorgensen, 1992; Overnell et al., 1995).

Because of its resistance to microbial degradation, the use of lignin as a tracer to study land-derived OM has been well documented (Hedges and Parker, 1976; Hedges and Ertel, 1982; and references therein). Numerous studies have used lignin to study the distribution of marine and land-derived OM (Hedges and Parker, 1976; Wilson et al., 1985; Mitra et al., 2000). The importance of riverine inputs contributing terrestrial debris into near shore sediments is also well documented (Liss et al., 1991; Milliman, 1991; Ward et al., 1994), as is an offshore decrease of lignin-derived phenols (Hedges

Published by Copernicus Publications on behalf of the European Geosciences Union. 


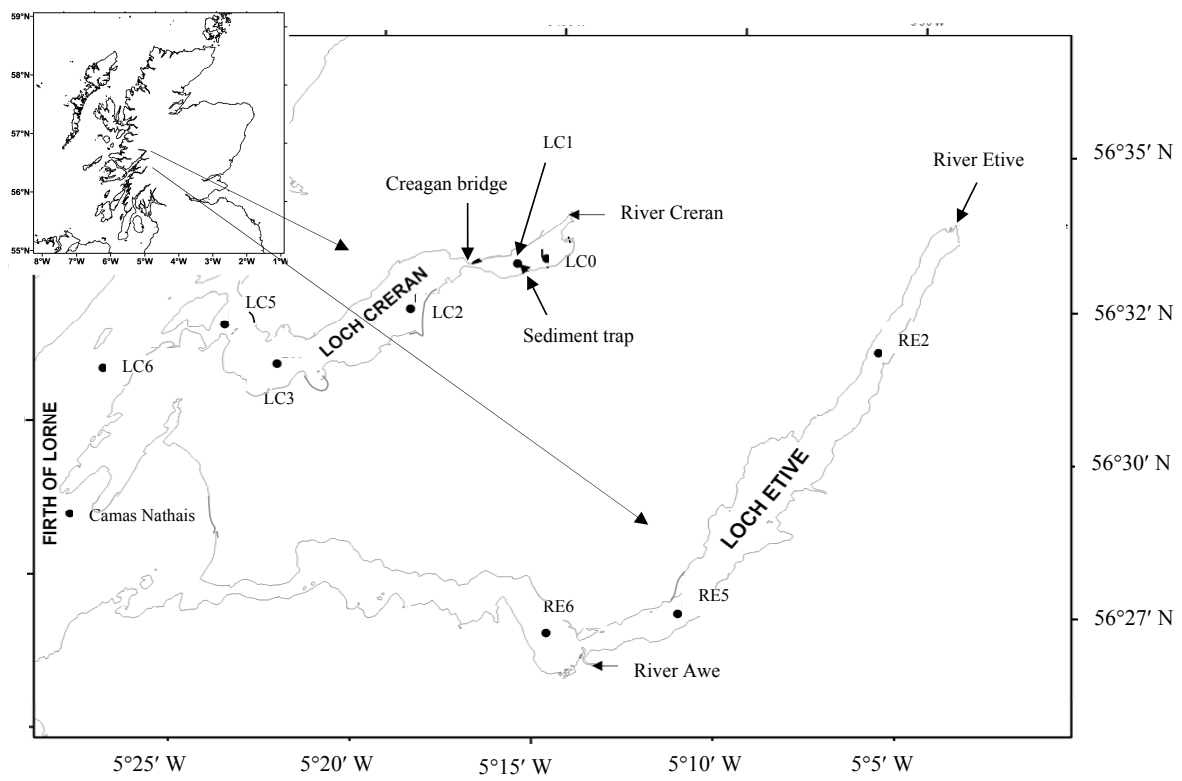

Fig. 1. Map of study area showing the sampling locations (inset, map of Scotland).

Table 1. Sampling locations and water depths in Lochs Creran and Etive (surface sediments and sediment trap).

\begin{tabular}{lcccc}
\hline Lochs & Sampling locations & Water depth $(\mathrm{m})$ & Latitude $(\mathrm{N})$ & Longitude $(\mathrm{W})$ \\
\hline Loch Creran & LC0 & 15.42 & $56^{\circ} 33^{\prime}$ & $05^{\circ} 15^{\prime}$ \\
& LC1 & 37 & $56^{\circ} 33^{\prime}$ & $05^{\circ} 16^{\prime}$ \\
& LC2 & 17 & $56^{\circ} 32^{\prime}$ & $05^{\circ} 19^{\prime}$ \\
& LC3 & 49 & $56^{\circ} 31^{\prime}$ & $05^{\circ} 23^{\prime}$ \\
& LC5 & 13 & $56^{\circ} 32^{\prime}$ & $05^{\circ} 24^{\prime}$ \\
& LC6 & 48.94 & $56^{\circ} 31^{\prime}$ & $05^{\circ} 27^{\prime}$ \\
& Sediment trap & 10 & $56^{\circ} 33^{\prime}$ & $05^{\circ} 16^{\prime}$ \\
\hline \multirow{2}{*}{ Loch Etive } & RE2 & 37 & $56^{\circ} 32^{\prime}$ & $05^{\circ} 06^{\prime}$ \\
& RE5 & 123 & $56^{\circ} 27^{\prime}$ & $05^{\circ} 11^{\prime}$ \\
& RE6 & 57 & $56^{\circ} 27^{\prime}$ & $05^{\circ} 15^{\prime}$ \\
& Camas Nathais & 20 & $56^{\circ} 29^{\prime}$ & $05^{\circ} 28^{\prime}$ \\
\hline
\end{tabular}

and Parker, 1976; Miltner and Emeis, 2001; Bianchi et al., 2002). Studies conducted at the Lower St. Lawrence Estuary and Saguenay Fjord further reported lignin, together with $\mathrm{OC}$, total nitrogen and organic phosphate to indicate OM diagenesis (Louchouarn et al., 1997).

Lignin compounds are found only in vascular land plants (Sarkanen and Ludwig, 1971). These lignin phenols can be used to characterize different vegetation sources: for example, elevated $\mathrm{S} / \mathrm{V}$ ratios are indicative of angiosperm tissues, whilst elevated $\mathrm{C} / \mathrm{V}$ ratios indicate the presence of nonwoody tissues (Hedges and Mann, 1979b; Bianchi and Argyrou, 1997; Goni et al., 1998). The vanillic acid to vanillin ratio, $(\mathrm{Ad} / \mathrm{Al}) \mathrm{v}$ is indicative of the diagenetic state, as relatively high $(\mathrm{Ad} / \mathrm{Al}) \mathrm{v}$ indicates more degraded material (Hedges et al., 1982; Miltner and Emeis, 2001). Lignin parameters such as $\mathrm{C} / \mathrm{V}, \mathrm{S} / \mathrm{V}$ and $(\mathrm{Ad} / \mathrm{Al}) \mathrm{v}$ ratios, along with molar $\mathrm{OC} / \mathrm{N}$ ratios, have been used to study lignin diagenesis (Ishiwatari and Uzaki, 1987).

A valuable tool for linking OM source to sediment biodegradability is the $R p$ index (Kristensen, 1990). Calculated as the ratio of the refractory to total OM, the author showed that the more easily degradable environmental samples have lower $R p$ values, and vice versa. $R p$ values, in conjunction with molar $\mathrm{OC} / \mathrm{N}$ ratio, provide a strong tool to measure the OM biodegradability. During the initial stages of OM degradation the $\mathrm{OC} / \mathrm{N}$ ratio increases due to preferential nitrogen utilization; later decreasing due to nitrogen immobilization (Benner et al., 1991). Increase in the OC/N ratio also implies the presence of plant materials which have a higher proportion of $\mathrm{C}$ to $\mathrm{N}$ than marine $\mathrm{OM}$ (Pocklington, 
1976), whilst a decrease in the OC/N ratio, with an associated increase in $(\mathrm{Ad} / \mathrm{Al}) \mathrm{v}$, indicates diagenesis (Pocklington and MacGregor, 1973). The hypothesis of this study was that oxygen uptake rates, molar $\mathrm{OC} / \mathrm{N}$ ratio and $R p$ values could be used as proxies to indicate biodegradability of sedimentary OM in sea loch systems.

\section{Materials and methods}

\subsection{Study areas}

Loch Creran and Loch Etive are neighbouring sea lochs located on the west coast of Scotland (Fig. 1). Over the lower ground surrounding the lochs and rivers, deciduous plants such as oak, beech and birch dominate. Gymnosperms such as spruce cover the higher ground.

\subsubsection{Loch Creran}

Loch Creran is $12.8 \mathrm{~km}$ long with a surface area of $13.5 \mathrm{~km}^{2}$. This loch has a relatively small catchment area of $164 \mathrm{~km}^{2}$. The mean freshwater input is $286 \times 10^{6} \mathrm{~m}^{3} \mathrm{yr}^{-1}$ and the flushing time is three days (Edwards and Sharples, 1986). Since Loch Creran is relatively small and shallow, the seasonal hydrography follows the pattern of the Firth of Lorne and tidal flushing is sufficient to ensure mixing throughout the water column (Gage, 1972). There are four sills which separate the loch into distinct basins. There are five sampling locations situated along the length of the loch: LC0, LC1, LC2, LC3 and LC5; LC6 is located outside the loch in the Firth of Lorne. LC0 and LC1 are situated in the upper basin of the loch, after the sill at Creagan Bridge; LC2, LC3 and LC5 are situated in the second basin, between the sill at Creagan Bridge and the sill separating the entrance to the loch from the Firth of Lorne. River Creran, at the head, is the major source of freshwater input to the loch (Table 1, Fig. 1).

\subsubsection{Loch Etive}

The larger of the two lochs, Loch Etive, is $29.5 \mathrm{~km}$ long with surface area of $28.3 \mathrm{~km}^{2}$ and catchment of $1400 \mathrm{~km}^{2}$ (Gage, 1972; Wood et al., 1973; Edwards and Edelstens, 1977). The mean freshwater input is $3037.5 \times 10^{6} \mathrm{~m}^{3} \mathrm{yr}^{-1}$ (Edwards and Sharples, 1986). Loch Etive is characterized by prolonged periods of water stratification. The residence time of isolated bottom waters may extend up to 30 months, with a mean of 16 months (Edwards and Trusdale, 1997). Periodic intense freshwater inflow, following prolonged periods of low freshwater runoff, controls an occasional ventilation and replenishment of the deep basins (Gage, 1972; Edwards and Grantham, 1986; Edwards and Trusdale, 1997). Loch Etive has a sill at the seaward entrance to the lower loch (Falls of Lora), and a shallow narrow at the opening to the upper loch (Bonawe). Sampling sites RE2 and RE5 are located in the upper loch, RE6 in the lower loch and Camas Nathais in the
Firth of Lorne (Table 1, Fig. 1). The major freshwater inputs are River Etive at the head of the loch, and River Awe at Bonawe (Gage, 1972; Edwards and Sharples, 1986).

\subsection{Sampling and sample pre-treatment}

Three undisturbed sediment cores were obtained from each location using a Craib corer (Craib, 1965) lined with an acrylic core tube of $24 \mathrm{~cm}$ long $\times 5.9 \mathrm{~cm}$ i.d. Site $\mathrm{LC} 1$ was visited at monthly intervals. All other locations were visited every four months. Loch Etive was visited for three consecutive months. A sediment trap was deployed in Loch Creran (see Table 1 for location) $10 \mathrm{~m}$ below the surface (m.b.s.) of water. The trap consisted of four collecting tubes (dimensions: $11 \mathrm{~cm}$ internal diameter and $100 \mathrm{~cm}$ in length) and was serviced once a month. In the laboratory, sediments in the collecting tubes were allowed to settle, and the overlying water was siphoned off. The sediment slurry was then centrifuged at $600 \times \mathrm{g}$ for $10 \mathrm{~min}$ and, after pouring off the supernatant, was subjected to freeze-drying.

In the laboratory, oxygen uptake rates were measured on whole sediment cores. Upon completion, the top $1 \mathrm{~cm}$ slice was removed from each core, frozen overnight and freezedried the following day. Dried sediments were then ground to fineness using a pestle and mortar for the lignin, loss on ignition and bulk elemental determinations.

\subsection{Analytical methods}

\subsubsection{Oxygen uptake rate analysis}

Oxygen uptake rates were determined by measuring the decrease in dissolved oxygen concentration in the overlying water from incubated intact sediment cores (Parkes and Buckingham, 1986; Glud et al., 1994; Overnell et al., 1995). After collection, the core tubes were sealed with rubber bungs and transported back to the laboratory (Overnell et al., 1995). Here the cores were transferred to a container of seawater collected from 10 m.b.s. at the sampling site (i.e. below the mixed layer). The cores were kept overnight in the dark at in situ temperature, with the upper bungs removed. The overlying water column was gently aerated to maintain a saturated dissolved oxygen concentration. On the following day, submersible stirrers were fitted onto the core tubes, thus isolating the core and its overlying water. The stirring rate was adjusted to prevent stagnation of the overlying water without causing sediment resuspension and in order to maintain uniform oxygen concentrations (Overnell et al., 1995). At time zero, replicate water samples were collected from the container using $10 \mathrm{ml}$ glass syringes. The samples were fixed immediately following collection. Every $10 \mathrm{ml}$ water sample was fixed with $0.1 \mathrm{ml}$ alkaline iodide and $0.1 \mathrm{ml}$ of $\mathrm{MnSO}_{4}$. The cores were incubated for twenty four hours, after which three samples were collected from the overlying water of each core and fixed. The dissolved oxygen concentration was 
measured by Winkler titration with potentiometric detection of the end point (Hansen, 1999). The oxygen uptake rate was calculated from the difference in oxygen concentration of the overlying water between the start and end of the incubation. Method validation was based on repeated analyses of samples: 15 replicates of a single sample, plus routine triplicate analyses of all samples for environmental interpretation. The precision determined was over the range $0.10-7.90 \%$ coefficient of variation. Oxygen uptake rates were calculated after Skoog et al. (1996) and Hansen (1999).

\subsubsection{Lignin analysis}

The alkaline $\mathrm{CuO}$ oxidation method used to extract ligninderived phenols from environmental samples follows the methods detailed in previous studies (Hedges and Ertel, 1982; Readman et al., 1986; Goni and Hedges, 1992). The $\mathrm{CuO}$ oxidation method used in this study has been described by Loh et al. (2002, 2008); it consists of a series of steps involving oxidation, extraction, silylation and finally detection of a suite of eight simple lignin phenols, as their trimethylsilylated forms, by gas chromatography (Hedges et al., 1982; Miltner and Emeis, 2000).

Approximately $0.5 \mathrm{~g}$ dry sediment was oxidized at $155^{\circ} \mathrm{C}$ for three hours with $1.0 \mathrm{~g} \mathrm{CuO}$ and $7 \mathrm{ml}$ of $8 \% \mathrm{w} / \mathrm{v} \mathrm{NaOH}$ solution in an oxygen free atmosphere, in a PTFE-lined stainless-steel reaction vessel. Products which had been extracted three times with diethyl ether were spiked with the internal standard ethyl vanillin. The combined extracts and standards were treated with anhydrous $\mathrm{Na}_{2} \mathrm{SO}_{4}$, filtered and rotary evaporated to near dryness.

The dried extract was subjected to a silylation process, to convert lignin phenols to their more thermodynamically stable trimethylsilylated forms. The oxidation product was dissolved in $100 \mu \mathrm{l}$ dried toluene. An equal volume of bis(trimethylsilyl)trifluoroacetamide with $10 \%$ trimethylchlorosilane (BSTFA:TMCS=10:1; Sigma Aldrich) was added as a catalyst (Poole, 1979). Samples were heated at $90^{\circ} \mathrm{C}$ (Wilson et al., 1995) for $10 \mathrm{~min}$ and then analysed using a GC-FID (Perkin-Elmer 8410) fitted with a $0.25 \mathrm{~mm}$ i.d. $\times 30 \mathrm{~m}$ of $100 \%$ dimethylpolysiloxane (ZB-1, Phenomenex, Zebron) column and a split ratio of 100:1. The initial temperature was $100^{\circ} \mathrm{C}$, increased at $5^{\circ} \mathrm{C}$ per minute to $200^{\circ} \mathrm{C}$, and held for $10 \mathrm{~min}$. For the second ramp, the temperature increased at $20^{\circ} \mathrm{C}$ per minute to $300^{\circ} \mathrm{C}$ and this was held for $5 \mathrm{~min}$. Both injector and detector temperatures were $300^{\circ} \mathrm{C}$. The equilibration time was $2 \mathrm{~min}$.

Total lignin is the sum of vanillyl (V; vanillin, acetovanillone and vanillic acid) syringyl (S; syringaldehyde, acetosyringone and syringic acid) and cinnamyl $(\mathrm{C}$; $\mathrm{p}$-coumaric and ferulic acids) phenols, reported as $\Lambda$ (mg/100 mg organic carbon, OC; Hedges and Mann, 1979a). Based on replicate analyses the range of sample reproducibilities for total lignin concentrations was $7.8-37.4 \%$ (coefficient of variation).
Gas chromatography with mass spectrometry (GC-MS) analysis was used to confirm the chemical nature of the lignin phenol compounds (Hedges and Parker, 1976; Onstad et al., 2000): a TRACE MS Thermo Quest, Finnigan instrument was used, fitted with a $0.25 \mathrm{~mm}$ i.d. $\times 30 \mathrm{~m}$ of $5 \%$ phenylmethylpolysiloxane capillary column (RTX-5MS, RESTEK CORP.), employing a split ratio 100:1. The initial temperature was $100^{\circ} \mathrm{C}$, increasing at $5^{\circ} \mathrm{C}$ per minute to $200^{\circ} \mathrm{C}$, and held for $10 \mathrm{~min}$. For the second ramp, temperature was increased at $20^{\circ} \mathrm{C}$ per minute to $300^{\circ} \mathrm{C}$. The inlet temperature was $300^{\circ} \mathrm{C}$, the oven maximum temperature was $350^{\circ} \mathrm{C}$ and the equilibration time was $0.5 \mathrm{~min}$.

\subsubsection{Loss on ignition}

Significant losses of mass between $250^{\circ} \mathrm{C}$ and $300^{\circ} \mathrm{C}$ have been observed (Mook and Hoskin, 1982); hence $250^{\circ} \mathrm{C}$ was used in this work as the initial combustion temperature. Although it is difficult to determine the exact nature of the material burned off at $500^{\circ} \mathrm{C}$, it is likely that most refractory terrestrial and aquatic $\mathrm{OM}$ will be included. Most inorganic carbon has been shown to oxidize above $500^{\circ} \mathrm{C}$ (Hirota and Szyper, 1975; Kristensen and Andersen, 1987); hence $500^{\circ} \mathrm{C}$ was used as the higher temperature.

Method validation was carried out by subjecting a single sample to repeated analyses. Approximately $0.5 \mathrm{~g}$ aliquots of dried sediment were weighed precisely into crucibles. These were ashed $\left(250^{\circ} \mathrm{C}\right.$ for $\left.16 \mathrm{~h}\right)$ in a muffle furnace, cooled and reweighed. Sediments were then heated to $500^{\circ} \mathrm{C}$ (Kristensen and Andersen, 1987) for 16h (Sutherland, 1998), cooled and reweighed. The percentage weight losses after combustion at these two temperatures were defined as the $\%$ labile and $\%$ refractory OM respectively. The sum of $\%$ labile and \% refractory OM was taken to be the \% total OM. The $R p$ value, which is defined as the ratio of the refractory to total OM, is used to determine the stage of decomposition of biogenic materials (Kristensen, 1990). Percentage reproducibility obtained from validation experiments and sample analyses were within the range 10-20\% coefficient of variation.

\subsubsection{Bulk elemental and isotope analyses}

For organic carbon $(\% \mathrm{OC})$ and total nitrogen $(\% \mathrm{TN})$ determinations, approximately $10 \mathrm{mg}$ sediment samples were acidified with $1 \mathrm{ml}$ of $5 \% \mathrm{w} / \mathrm{v}$ sulphurous acid in vials. These were allowed to stand overnight in a fume cupboard and were subsequently freeze-dried. The product was quantitatively transferred into tin capsules and CHN analyses were performed in triplicate using a LECO CHN-900 analyzer. For total carbon (TC) determination, $10 \mathrm{mg}$ dry sediment was transferred into $8 \times 5 \mathrm{~mm}$ tin capsules and analysed similarly. Sample reproducibilities for the \% TC and \% TN ranged from $0-20.6 \%$ and $0-19.2 \%$, respectively. 
Table 2. Lignin parameters for Lochs Creran and Etive (surface sediments and sediment traps).

\begin{tabular}{lccccccc}
\hline Loch Creran & Sediment trap & LC0 & LC1 & LC2 & LC3 & LC5 & LC6 \\
\hline V (mg/g) & 0.13 & 0.15 & 0.09 & 0.08 & 0.03 & 0.05 & 0.02 \\
S (mg/g) & 0.09 & 0.09 & 0.06 & 0.05 & 0.02 & 0.02 & 0.01 \\
C (mg/g) & 0.08 & 0.09 & 0.07 & 0.05 & 0.02 & 0.03 & 0.02 \\
Total lignin (mg/g) & 0.30 & 0.33 & 0.22 & 0.18 & 0.07 & 0.10 & 0.05 \\
Total lignin, $\Lambda$ (mg/100 mg OC) & 0.50 & 0.69 & 0.55 & 0.58 & 0.39 & 0.43 & 0.45 \\
S/V & 0.69 & 0.60 & 0.67 & 0.63 & 0.67 & 0.40 & 0.50 \\
C/V & 0.62 & 0.60 & 0.78 & 0.63 & 0.67 & 0.60 & 1.00 \\
(Ad/Al)v & 2.69 & 1.07 & 0.83 & 0.96 & 1.19 & 0.52 & 0.90 \\
\hline Loch Etive & RE2 & RE5 & RE6 & Camas Nathais & & & \\
V (mg/g) & 0.16 & 0.14 & 0.14 & 0.03 & & & \\
S (mg/g) & 0.17 & 0.14 & 0.14 & 0.02 & & & \\
C (mg/g) & 0.09 & 0.07 & 0.07 & 0.01 & & & \\
Total lignin (mg/g) & 0.42 & 0.35 & 0.35 & 0.06 & & & \\
Total lignin, $\Lambda$ (mg/100 mg OC) & 0.70 & 0.71 & 0.71 & 0.29 & & & \\
S/V & 1.06 & 1.00 & 1.00 & 0.67 & & & \\
C/V & 0.56 & 0.50 & 0.50 & 0.33 & & & \\
(Ad/Al)v & 0.74 & 0.72 & 0.71 & 0.52 & & &
\end{tabular}

Abbreviations: $\mathrm{V}=$ vanillyl phenols (sum of vanillin, acetovanillone and vanillic acid); $\mathrm{S}=$ syringyl phenols (sum of syringaldehyde, acetosyringone and syringic acid); $\mathrm{C}=$ cinamyl phenols (sum of p-coumaric and ferulic acids); $\Lambda=\operatorname{sum}$ of $\mathrm{V}+\mathrm{S}+\mathrm{C}(\mathrm{mg} / 100 \mathrm{mg} \mathrm{OC}) ; \mathrm{S} / \mathrm{V}=$ ratio of syringyl:vanillyl phenols; $\mathrm{C} / \mathrm{V}=$ ratio of cinnamyl:vanilly phenols; $(\mathrm{Ad} / \mathrm{Al}) \mathrm{v}=$ ratio of the vanillic acid to vanillin $\left(\mathrm{Loh}\right.$ et al., $\left.2008^{1}\right)$.

${ }^{1}$ The lignin data was previously used as the biomarker for terrestrial OM in our studies to determine the fate of terrestrial OM in the lochs (Loh et al., 2008).

For the carbon isotope determination, approximately $0.1 \mathrm{mg}$ dried sediment was weighed into a $8 \times 5 \mathrm{~mm}$ tin capsule and analysed using a 20-20 Stable Isotope Analyzer (PD2 Europa Scientific Instruments). Percentage reproducibilities ranged from $0.0-16.9 \%$. The standard used was L-isoleucine, which was pre-calibrated against a Pee Dee Belemnite (PDB; Bashkin, 2002) standard. The $\delta^{13} \mathrm{C}$ value was calculated from the measured carbon isotope ratios of the sample and standard gases (Degens, 1969; Boutton, 1991):

$\delta^{13} \mathrm{C}(\% \circ)=\times 10^{3}$

where $R_{\text {sample }}={ }^{13} \mathrm{C} /{ }^{12} \mathrm{C}$ ratio in the sample, and $R_{\text {standard }}={ }^{13} \mathrm{C} /{ }^{12} \mathrm{C}$ ratio in the standard.

\subsubsection{Statistical analyses}

Single factor ANOVA was used to determine whether there is any significant difference of results between sampling times. Regression analyses were used to determine whether there are significant correlations among these parameters: lignin, oxygen uptake rates, labile, refractory and total $\mathrm{OM}, \mathrm{OC}, R p$ values and $\mathrm{OC} / \mathrm{N}$ ratios.

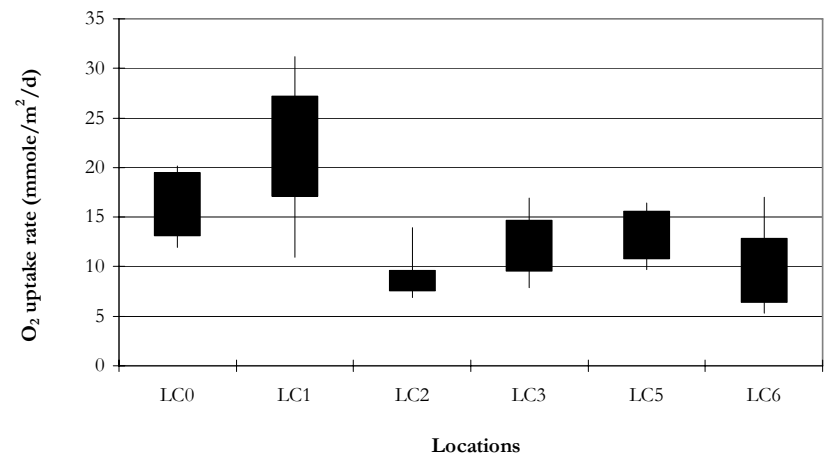

Fig. 2. Mean oxygen uptake rates for sediment cores from locations in Loch Creran. Each bar represents the highest and lowest values, and the first and third quartiles of the data.

\section{Results}

\subsection{Yields of land-derived organic matter}

Overall, lignin parameters at individual locations exhibited no distinct change with time hence these have been averaged for presentation in Table 2. There was no temporal variation in either sediment trap or sedimentary organic matter. The range of $\Lambda$ values in Loch Creran and Loch Etive (0.29 to 0.71 ; Table 2) are within limits reported for riverine, estuarine and marine sediments (Hedges and Mann, 1979b; 
Table 3. Average oxygen uptake rates in Loch Creran.

\begin{tabular}{|c|c|c|c|c|c|c|c|c|c|c|c|}
\hline \multirow[t]{2}{*}{ Locations } & \multicolumn{11}{|c|}{ Oxygen uptake rate $\left(\mathrm{mmole} / \mathrm{m}^{2} /\right.$ day) for 2002} \\
\hline & Mar & Apr & May & Jun & Jul & Aug & Sep & Oct & Nov & Dec & Mean \\
\hline LC0 & & $18.7>$ & 16.7 & & & & & & 15.9 & & 17.1 \\
\hline $\mathrm{LC} 1$ & & $14.5<$ & 21.2 & $18.7<$ & 26.4 & $27.8>$ & $23.5>$ & 18.9 & $24.3>$ & 11.8 & 20.8 \\
\hline $\mathrm{LC} 2$ & & 9.2 & & & & & & 9.6 & & & 9.4 \\
\hline LC3 & $9.0<$ & 13.6 & & & & & & 14.8 & & & 12.5 \\
\hline LC5 & 12.3 & & & & $14.4<$ & & & & & 18.7 & 15.1 \\
\hline LC6 & 6.6 & & & & & $14.2>$ & & 7.5 & & & 9.4 \\
\hline
\end{tabular}

The oxygen uptake rates were measured every month at LC1, but for the other locations, they were visited in successive orders. The symbols ">" and " $<$ " indicate significantly more and less than the value in the following month (ANOVA: $p<0.05$ ).

Readman et al., 1986; Requejo et al., 1986; Ishiwatari and Uzaki, 1987; Prahl et al., 1994; Goni et al., 1997 and 1998; Goni et al., 2000; Miltner and Emeis, 2001; Bianchi et al., 2002). It was found that vanillyl phenols are the major lignin oxidation products, followed by the syringyl and cinnamyl phenols.

In Loch Creran, the highest $\Lambda$ values (0.69) were found in LC0 surface sediments. Further down the loch, $\Lambda$ decreased to 0.55 at LC1, and increased slightly to 0.58 at LC2, decreased to 0.39 at LC3, and increased slightly again to 0.43 (LC5) and 0.45 (LC6). Similarly to Loch Creran, Loch Etive also displays lower lignin content away from the freshwater input (ANOVA: $p<0.05$ between RE2, RE5 and RE6 with Camas Nathais). Compared to Loch Creran, however, all three stations (RE2, RE5 and RE6) in Loch Etive displayed a higher yield of total lignin, with $\Lambda$ ranging from 0.70 to 0.71 . Camas Nathais in the Lynn of Lorn had by far the lowest $\Lambda$ of 0.29 (ANOVA: $p<0.05$ ). Sediments from LC0 surface sediments show the most depleted $\delta^{13} \mathrm{C}$ values of $-24.7 \%$, respectively. Sediments from LC6 have the most enriched values $\left(-14.6 \%\right.$ ). Similarly, in Loch Etive, the $\delta^{13} \mathrm{C}$ values increased seawards; RE2, RE5 and RE6 had an average $\delta^{13} \mathrm{C}$ value of approximately $-25.8 \%$, while Camas Nathais had the highest $\delta^{13} \mathrm{C}$ values of $-13.5 \%$.

\subsection{Proxies for sediment biodegradability}

\subsubsection{Oxygen uptake rates}

Results of the oxygen uptake rate analyses for Loch Creran are presented in Table 3. At LC0, these were highest during April (18.7 mmole $\mathrm{m}^{-2} \mathrm{day}^{-1}$ ) and decreased significantly during the following months (ANOVA: $p<0.05$ ). For other locations, it seems that higher oxygen uptake rates occurred later in the year. The mean oxygen uptake rate at LC1 was $20.8 \mathrm{mmole} \mathrm{m}^{-2} \mathrm{day}^{-1}$, whilst the observed trend for LC1 was an increase from July to November 2002. The significant differences (ANOVA: $p<0.05$ ) of the rates between some of the months are given in Table 3 . There are no significant differences (ANOVA: $p>0.05$ ) in the measured rates at $\mathrm{LC} 2$, whilst at $\mathrm{LC} 3$ the rate increased significantly (ANOVA: $p<0.05$ ) from March to April, and was highest in October. At LC5 and LC6 the highest oxygen uptake rates occurred during December and August respectively. The mean rate within the upper most basin ranged from 17.1 to 20.8 mmole m$^{-2}$ day $^{-1}$ (from LC0 to LC1) and in the middle basin from 9.4 to $15.1 \mathrm{mmole} \mathrm{m}^{-2} \mathrm{day}^{-1}$ (from LC2 to LC5). Oxygen uptake rates decreased significantly from the head to mouth of the loch (ANOVA: $p<0.05$; Fig. 2).

\subsubsection{Loss on ignition and bulk elemental composition}

As there was also no significant seasonal trend for the loss on ignition and bulk elemental results at individual locations, mean data are presented in Table 4 . The sediment trap material had the highest contents of labile (14.8\%), refractory $(8.7 \%)$ and total OM $(23.4 \%)$ compared to all surface sediments. However, during transport to the sediments, the OM and OC contents decreased significantly (ANOVA: $p<0.05$ ). Comparison between surface sediments shows that the location nearest the river input (LC0) had the highest labile $(9.8 \%)$, refractory $(7.3 \%)$ and total OM $(17.1 \%)$. Overall the $R p$ values increased significantly (ANOVA: $p<0.05$ ) from 0.43 at LC0 to 0.63 outside the loch at LC6, whilst the percentage labile, refractory and total OM decreased from the head to mouth of the loch. The surface sediment molar OC/N ratios in Loch Creran also decreased further down the loch: the highest was found at LCO (11.2) and the lowest at LC 6 (6.4). $R p$ values show negative correlation with total lignin (Loch Etive, $r^{2}=0.98$; Loch Creran $\left.r^{2}=0.90\right)$, \% TC $\left(r^{2}=0.91\right.$, $p<0.05, n=7)$ and $\% \mathrm{TN}\left(r^{2}=0.80, p<0.05, n=7\right)$ along the length of the lochs.

Similarly, the \% $\%$ TC, \% $\mathrm{TN}$, and \% $\mathrm{TOC}$ of surface sediments decreased significantly from the head to mouth of Loch Creran (ANOVA: $p<0.05$ ). Of the surface sediments, LC0 had the highest \% TC (5.1), \% TN (0.5) and \% TOC (4.8) whilst LC6 had the lowest contents of \% TC (1.9), \% TN (0.2) and \% TOC (1.1) respectively. Sediment trap material contained the highest \% TC (6.4) and \% TN (0.8). 
Table 4. Loss on ignition and bulk elemental results for Lochs Creran and Etive (surface sediments and sediment traps).

\begin{tabular}{|c|c|c|c|c|c|c|c|c|c|}
\hline \multirow[t]{2}{*}{ Site } & \multirow[t]{2}{*}{$\delta^{13} \mathrm{C}(\% \circ)$} & \multicolumn{4}{|c|}{ Loss on ignition } & \multicolumn{4}{|c|}{ Bulk elemental results } \\
\hline & & $\%$ labile OM & $\%$ refract $\mathrm{OM}$ & $\%$ TOM & $R p$ & $\% \mathrm{TC}$ & $\% \mathrm{TN}$ & $\%$ TOC & Molar OC/N \\
\hline \multicolumn{10}{|l|}{ Loch Creran } \\
\hline LC0 & -24.7 & 9.8 & 7.3 & 17.1 & 0.43 & 5.1 & 0.5 & 4.8 & 11.2 \\
\hline Sediment trap & -21.3 & 14.8 & 8.7 & 23.5 & 0.37 & 6.4 & 0.8 & 6.0 & 8.8 \\
\hline LC1 & -23.8 & 9.1 & 6.8 & 15.9 & 0.43 & 4.6 & 0.5 & 4.0 & 9.3 \\
\hline LC2 & -23.8 & 6.8 & 6.1 & 12.9 & 0.47 & 3.6 & 0.4 & 3.1 & 9.0 \\
\hline LC3 & -17.3 & 3.5 & 4.9 & 8.4 & 0.58 & 2.7 & 0.3 & 1.8 & 7.0 \\
\hline LC5 & -21.0 & 1.3 & 3.2 & 4.5 & 0.71 & 3.3 & 0.3 & 2.3 & 8.9 \\
\hline LC6 & -14.6 & 3.6 & 6.0 & 9.6 & 0.63 & 1.9 & 0.2 & 1.1 & 6.4 \\
\hline \multicolumn{10}{|l|}{ Loch Etive } \\
\hline RE2 & -25.8 & 10.6 & 7.1 & 17.7 & 0.40 & 6.3 & 0.4 & 6.0 & 17.5 \\
\hline RE5 & -25.8 & 10.9 & 9.4 & 20.3 & 0.46 & 5.6 & 0.5 & 4.9 & 11.4 \\
\hline RE6 & -25.7 & 11.7 & 11.1 & 22.8 & 0.49 & 5.8 & 0.5 & 4.9 & 11.4 \\
\hline Camas Nathais & -13.5 & 3.0 & 12.1 & 15.1 & 0.80 & 3.5 & 0.3 & 2.1 & 8.2 \\
\hline
\end{tabular}

Abbreviations: $\mathrm{OM}=$ organic matter; TOM $=$ total organic matter; $R p=\%$ refractory $/ \% \mathrm{TOM}\left(\right.$ Loh et al., $\left.2008^{2}\right)$.

2 The loss on ignition and bulk elemental results were previously used in Loh et al (2008) to determine the fate of terrestrial OM in the water column, during transportation down the lochs, and upon burial in the sediment.

In Loch Etive the \% labile OM was relatively constant from RE2 to RE6, whilst \% refractory OM increased by $\sim 56 \%$. RE2, situated nearest the river input, had the highest \% TC and \% TOC and molar OC/N ratio. RE5 and RE6 had almost the same values for these variables and \% TN.

At Camas Nathais there was a dramatic decrease in \% labile OM (74\% lower than RE6), whilst \% refractory OM remained of a similar order to the other stations: the lowest $\% \mathrm{TC}, \% \mathrm{TN}, \% \mathrm{TOC}$ and molar OC/N ratio were also observed here. Seemingly, during transportation the OM undergoes decomposition; hence the OM at Camas Nathais was relatively highly degraded.

\section{Discussion}

\subsection{Sources of terrestrial organic matter}

The distribution of total OM and OC in both lochs is largely influenced by the terrestrial inputs from River Creran to Loch Creran, and Rivers Etive and Awe to Loch Etive. Vanillyl phenols were present in greater amounts than syringyl and cinnamyl phenols (Table 2), most probably because vanillyl phenols are produced by both angiosperms and gymnosperms; while syringyl phenols are produced only by angiosperms (Sarkanen and Ludwig, 1971; Hedges and Mann, 1979b; Hedges et al., 1982). Total lignin ( $\Lambda, \mathrm{mg} / 100 \mathrm{mg}$ OC) in the upper Loch Creran surface sediments ranged from 0.54 to 0.69 , and in the lower loch from 0.39 to 0.45 . The $\Lambda$ values in the upper Loch Etive surface sediments ranged from 0.70 to 0.71 , falling to 0.29 at Camas Nathais. River Awe, which drains into the loch between RE5 and RE6, most probably contributes to the high lignin and OM contents at both sites. These results demonstrate the importance of Rivers $\mathrm{Cr}$ eran, Etive and Awe, contributing terrestrial materials to the respective lochs. This is also supported by the gradual increased of $\delta^{13} \mathrm{C}$ values from the head to mouth of the lochs. $\delta^{13} \mathrm{C}$ values from $-22 \%$ to $-35 \%$ indicate the dominance of terrestrial OM (Cerling et al., 1995; Goni and Thomas, 2000), $\delta^{13} \mathrm{C}$ values from $-12 \%$ to $-23 \%$ indicate marine OM (Gearing et al., 1984; Ruttenberg and Goni, 1997; Gordon and Goni, 2003), and $\delta^{13} \mathrm{C}$ values from $-11 \%$ o to $-16 \%$ o indicate contribution of C4 plants (Boom et al., 2001).

The contribution of terrestrially-derived materials to the sedimentary carbon inventory in the lochs was investigated by correlating total lignin with total OM and TC (Table 5). Total lignin was highly correlated with \% total OM and TC suggesting that terrestrial materials make a major contribution to total $\mathrm{OM}$ and TC in both lochs (regression analysis: $p<0.05$ ). \% TC shows significant correlation (regression analyses: $p<0.05$ ) with total lignin in Loch Creran. Terrestrial material contributes significantly to the total OM and specifically to the labile fraction of OM, as shown by significant relationships for total lignin with \% labile OM and with $\%$ total OM along the length of Loch Creran, and lignin versus \% labile OM in Loch Etive (Table 5). The importance of terrestrial OM fuelling the biogeochemical cycling of carbon in the lochs was explained in better details by Loh et al. (2008).

Degradation of lignin is a slow process owing to its complex nature (Hurst and Burges, 1967; Zeikus, 1980). Some authors found no quantifiable lignin degradation in aerobic 
Table 5. Correlation and regression analyses.

\begin{tabular}{ll}
\hline & Correlation and regression results \\
\hline Between oxygen uptake rates and: & \\
LC1 total lignin & $r=-0.08$ \\
Loch Creran total lignin & $r=0.58, r^{2}=0.33, p>0.05, n=6$ \\
Loch Creran labile OM & $r=0.51, r^{2}=0.26, p>0.05, n=6$ \\
Loch Creran OC & $r=0.69, r^{2}=0.48, p>0.05, n=6$ \\
\hline Between lignin and: & \\
Loch Creran \% labile OM & $r=0.93, r^{2}=0.87, p<0.05, n=6$ \\
Loch Creran \% refractory OM & $r=0.39, r^{2}=0.15, p>0.05, n=6$ \\
Loch Creran \% total OM & $r=0.83, r^{2}=0.68, p<0.05, n=6$ \\
Loch Creran \% Rp & $r=-0.95, r^{2}=0.90, p<0.05, n=6$ \\
Loch Etive \% labile OM & $r=0.97, r^{2}=0.93, p<0.05, n=4$ \\
Loch Etive \% refractory OM & $r=-0.75, r^{2}=0.56, p>0.05, n=4$ \\
Loch Etive \% total OM & $r=0.68, r^{2}=0.47, p>0.05, n=4$ \\
Loch Etive \% $R p$ & $r=-0.99, r^{2}=0.84, p<0.05, n=4$ \\
\hline Between lignin and $\delta^{13} \mathrm{C:}$ & \\
Sediment trap & $r=-0.68, r^{2}=0.47, p<0.05, n=13$ \\
Loch Creran & $r=-0.76, r^{2}=0.58, p<0.05, n=19$ \\
Loch Etive & $r=-0.96, r^{2}=0.93, p<0.05, n=4$ \\
\hline Between lignin and \%OC: & \\
Loch Creran & $r=0.85, r^{2}=0.73, p<0.05, n=6$ \\
Loch Etive & $r=0.95, r^{2}=0.91, p<0.05, n=4$ \\
\hline Labile OM versus OC & $r=0.96, r^{2}=0.92, p<0.05, n=7$ \\
\hline Between OC/N ratio and: & \\
Loch Creran lignin & $r=0.96, r^{2}=0.72, p<0.05, n=6$ \\
Loch Creran $R p$ values & \\
Loch Creran OC & \\
\hline &
\end{tabular}

aquatic environments (Hedges et al., 1986; Ertel et al., 1986; Hamilton and Hedges, 1988) or in anaerobic environments (Eriksson et al., 1990). As a result of these findings, lignin is thought to be found in the refractory OM fraction. This has not been identified in the systems studied here: lignin contents do not have any correlation with the refractory fraction of OM (Table 5). Whilst this may be due to the masking effects of variable inputs/components of the total OM, it may also indicate that refractory material includes lignin that has undergone diagenesis to an undefined "humic" structure (Hurst and Burges, 1967; Christman and Oglesby, 1971; Zeikus, 1980; Hedges and Oades, 1997).

The characteristics, or sources, of plant materials are also determined from the syringyl/vanillyl (S/V) and cinnamyl/vanillyl (C/V) ratios (Bianchi and Argyrou, 1997; Goni et al., 1998). As angiosperms produce more $\mathrm{S}$ than $\mathrm{V}$ phenols, and gymnosperms produce only $\mathrm{V}$, higher $\mathrm{S} / \mathrm{V}$ ratios indicate a higher abundance of angiosperms. As only nonwoody tissues produce $\mathrm{C}$ phenols, higher $\mathrm{C} / \mathrm{V}$ ratios are indicative of non-woody materials (Leo and Barghoorn, 1970; Sarkanen and Ludwig, 1971; Hedges and Mann, 1979b; Miltner and Emeis, 2001). The S/V ratios in Loch Creran and Loch Etive ranged from 0.40 to 1.06, with a mean value of 0.59 (from LC0 to LC5 surface sediments) within Loch Creran, and 0.94 (from RE2 to RE6) in Loch Etive. The range of $\mathrm{C} / \mathrm{V}$ ratios in both lochs is $0.33-1.00$, with mean values of 0.66 within Loch Creran and 0.52 within Loch Etive. The S/V and C/V ratios in both lochs are higher than at other locations: for example the Washington continental shelf and slope (Hedges and Mann, 1979a; Prahl et al., 1994), Baltic Sea (Miltner and Emeis, 2001), Tamar Estuary (Readman et al., 1986) and Narragansett Bay Estuary (Requejo et al., 1986). Accordingly, these high ratios are indicative of the presence of non-woody angiosperm tissues (Hedges and Parker, 1976; Goni et al., 2000). These non-woody tissues most probably originate from the leaves of plants commonly found around the loch catchments: Hedges and Mann (1979a) considered leaves as the non-woody tissue of a plant.

\subsection{Proxies for sediment biodegradability}

\subsubsection{Oxygen uptake rate}

The oxygen uptake rates determined in this study ranged from 6.6 to $27.8 \mathrm{mmole} \mathrm{m}^{-2} \mathrm{day}^{-1}$. These are within the rates determined previously in other lochs. The range of oxygen uptake rates determined in Loch Etive, Loch Eil and Tay Estuary were 13.6-17.8, 17.8-24.6 and $67.4 \mathrm{mmole} \mathrm{m}^{-2}$ day $^{-1}$, respectively (Parkes and Buckingham, 1986). The rates determined for Lochs Linnhe, Goil, Fyne and Etive ranged from 8 to 24 mmole m$^{-2}$ day $^{-1}$ (Overnell et al., 1995). The oxygen uptake rates in the Gulf of Lions ranged from 0.6 to $48 \mathrm{mmole} \mathrm{m}^{-2} \mathrm{day}^{-1}$ (Accornero et al., 2003). Oxygen uptake rates have previously been seen to increase near riverine discharge, implying the presence of a component of potentially degradable terrestrial material (Rowe et al., 1994; Overnell et al., 1995; Accornero et al., 2003). The various authors did not confirm the presence of terrestrial $\mathrm{OM}$ with a biomarker for terrestrial materials.

Seasonal studies show a slight increase in oxygen uptake rates at LC1 from July to September 2002; probably the result of enhanced microbial activity (Wassman, 1984; Parkes and Buckingham, 1986; Overnell et al., 1995). The oxygen uptake rates were averaged and showed a significant decrease from the head to mouth of Loch Creran (Fig. 2) in agreement with Overnell et al. (1995) and Loh et al. (2002). Overnell et al. (1995) determined the oxygen uptake rates for several locations along transect of Loch Etive: locations E2, E7 and E9 are represented as RE2, RE5 and RE6 respectively in this study. Oxygen uptake rates decreased from RE2 $\left(22.9 \mathrm{mmole}^{-2}\right.$ day $\left.^{-1}\right)$ to RE5 $\left(19.2 \mathrm{mmole}^{-2} \mathrm{day}^{-1}\right)$ and it is concluded that the high rate at RE6 (52.3 mmole $\mathrm{m}^{-2}$ day $\left.^{-1}\right)$ was most probably due to the influence of terrestrial input from the River Awe. The reoxidation of reduced species produced by, for example, sulphate reduction accounts for only $7-8 \%$ of the oxygen uptake rate (Overnell et al., 1995). 
Oxygen uptake rates were higher at LC5 in December 2002, and transect wise, higher at LC3 and LC5 than LC2. This fluctuation could be because LC5 is located in a sheltered area which accumulated more terrestrial $\mathrm{OM}$ and $\mathrm{OC}$ (Tables 2 and 4) which in turn increased the rate of OM degradation. Santos et al. (1994) also recognized small scale sampling heterogeneities on the spatial variability in the sedimentary organic matter quality and quantity in marine sediments. As result there was no significant correlation between oxygen uptake rates with the labile OM and OC (Table 5). There was, however, a significant decrease in oxygen uptake rates (ANOVA: $p<0.05$ ) progressing down the loch. Hence, results presented here are proposed to demonstrate a contribution from the degradation of terrestrial OM to the oxygen uptake rate. The highest total lignin $(\Lambda)$, \% labile OM, \% refractory OM, \% total OM, \% TC and \% TOC (Table 4) were found in the sediments near the riverine input. Besides, there were significant correlations between lignin and the labile and total OM and OC, and between the OM and OC (regression analysis: $p<0.05$ ). This clearly indicates a contribution of terrestrial OM to the carbon in the lochs. Hence, the decrease in oxygen uptake rates from the head to mouth of the lochs strongly implies that terrestrial OM fuels biogeochemical cycling in these systems. This terrestrially-derived OM appears to include much more labile material, with some susceptibility to decomposition in situ.

Our data support the use of the oxygen uptake rate as a proxy to measure sediment biodegradability, as increased rates indicate an increase in mineralization rates of OM. The oxygen uptake rate determination provides a measure of aerobic OM degradation at the sediment-water interface and is closely related to the sedimentary OM and carbon content. The overall significant decrease in the sediment oxygen uptake rates along the length of Loch Creran indicates that it can be used to provide an estimate of biodegradability.

\subsection{2 $R p$ index}

The $R p$ index can be used to provide an indirect measure of sediment biodegradability. As an operational ratio of the refractory to total OM concentrations, relatively high $R p$ values indicate more refractory OM, or decreased "freshness", or biodegradability, of the sedimentary OM. The usefulness of $R p$ values is enhanced by correlating them with other parameters such as lignin and molar $\mathrm{OC} / \mathrm{N}$ ratios. Lignin decreases down the lochs, indicating a reduction in the contribution of terrestrial materials seawards. $R p$ values show negative correlation with total lignin (Table 5) implying that lignin material and carbon content decreased through the lochs and the OM became increasingly refractory. Sedimentary OM has higher biodegradability near major riverine inputs.

The reason for decreasing lignin and OM concentrations (Tables 2 and 3) is due to (i) dilution with marine OM; (ii) sedimentation, as supported by the decrease in OM, OC and lignin contents from the head to the mouth of the lochs, as well as higher OM content in the trap than surface sediment; and (iii) $\mathrm{OM}$ decomposition, as indicated by the more highly degraded OM in surface sediments compared to trap materials.

The (Ad/Al)v values (Table 2) in Loch Creran and Loch Etive do not show a distinctive trend; implying that the lignin materials had not undergone significant degradation in the lochs. Conversely, the $R p$ values do show a trend: increasing through the lochs seawards, from LC0 (0.43) to LC6 (0.63), and from RE2 (0.40) to Camas Nathais (0.80) respectively. As the content of terrestrial OM decreased from the head to mouth of the lochs, this indicates that there was a fraction of labile terrestrial OM still susceptible to degradation. This labile fraction most probably caused the decreased of the oxygen uptake rates from the head to mouth of the lochs. The gradual increase in the refractory nature of the OM from the head to mouth of the lochs could be supported by the decreased in OC/N ratio. So, whilst it is clear that $R p$ index can be used as a measure of sediment biodegradability, this should be interpreted in the overall context of terrestrial $\mathrm{OM}$ loadings, oxygen uptake, and $\mathrm{OC} / \mathrm{N}$ ratio.

\subsubsection{Molar OC/N ratio}

It has long been known that fresh plant material has high nitrogen content and degrades rapidly (Waksman and Tenney, 1927). During the initial stage of OM degradation, molar $\mathrm{OC} / \mathrm{N}$ ratios increase due to nitrogen utilization (Benner et al., 1991). Care must be taken when interpreting OC/N ratios because sources of OM can also be indicated using these ratios; potentially providing an artefactual indication of degradation. For example, an $\mathrm{OC} / \mathrm{N}$ of $\sim 7$ points to a marine source of OM (Goni and Hedges, 1995; Bashkin, 2002) and $>20$ for terrestrial OM (Zimmerman and Canuel, 2001; Gordon and Goni, 2003). Bianchi and Argyrou (1997) and Bianchi et al. (2002) also found that terrestrial OM had higher $\mathrm{OC} / \mathrm{N}$ ratios compared to marine $\mathrm{OM}$. Hence, the molar OC/N ratios in the sediment trap (8.8), and at LC2 (9.0), LC5 (8.9), LC6 (6.4) and Camas Nathais (8.2) have a stronger marine signal than other locations; whilst LC0 (11.2), RE2 (17.5), RE5 (11.4) and RE6 (11.4) show greater terrestrial influence. This is supported by the significant correlations between $\mathrm{OC} / \mathrm{N}$ ratio with lignin and OC (Table 5).

The slightly higher $\mathrm{OC} / \mathrm{N}$ ratios for LC0 (mean $\mathrm{OC} / \mathrm{N}=11.2)$ and $\mathrm{LC} 1(\mathrm{OC} / \mathrm{N}=9.3)$ sediments, compared to the trap samples $(\mathrm{OC} / \mathrm{N}=8.8)$, could imply greater abundance of terrestrial $\mathrm{OM}$ in the surface sediments and more phytoplankton detritus in the trap. This proposition is supported by the higher $R p$ values for the LC0 $(R p=0.43)$ and LC1 $(R p=0.43)$ surface sediments compared to trap materials $(R p=0.37)$, which indicate more highly degraded plant materials in the surface sediments.

In trying to distinguish between vegetation source and OM degradation stage, $R p$ index data provide valuable information. In the later stages of degradation the $\mathrm{OC} / \mathrm{N}$ 
Table 6. Rate constants for the degradation of sedimentary OM within the $0-1 \mathrm{~cm}$ and $9-10 \mathrm{~cm}$ sediment layers.

\begin{tabular}{lccccc}
\hline Location & \multicolumn{5}{c}{ Rate constant, $k\left(\times 10^{-5} \mathrm{~d}^{-1}\right)$} \\
\hline \multirow{2}{*}{ LC0 } & Labile OM & Refractory OM & OC & TN & Lignin \\
LC1 & 2.2 & 3.5 & 1.0 & 2.3 & - \\
LC3 & 0.2 & 2.3 & 4.1 & 7.1 & 4.1 \\
LC5 & 1.3 & 1.5 & - & - & - \\
LC6 & - & 2.3 & - & - & 4.3 \\
\hline RE5 & - & - & - & - & 4.6 \\
RE6 (17.1.2001) & 1.3 & 1.7 & - & - & - \\
RE6 (20.3.2001) & 9.7 & - & - & - & - \\
\hline
\end{tabular}

The rate constant for the degradation of OM are determined only for the above during the occasions when the OM contents for the subsurface sediments were lower than the surface sediments, indicating OM degradation upon sedimentation. Besides, some of the data are not available for the subsurface $9-10 \mathrm{~cm}$ sediment layer.

ratios decrease due to nitrogen immobilization (Benner et al., 1991; Meyers, 1997). The decrease of OC/N ratios seawards through the lochs implies more advanced stages of OM degradation; this is seen by the more pronounced decrease of \% TOC compared to \% TN further down the lochs. In Loch Creran OC/N decreased from 11.2 to 6.4 and in Loch Etive from 17.5 to 8.2 . This is supported by the increase of $R p$ values from 0.43 to 0.63 , and from 0.40 to 0.80 respectively. Published studies have also shown decreasing OC/N ratios with advancing degradation stage for plants and soil materials: Berg et al. (1987) found that the OC/N ratios of plant materials decreased with increased incubation time due to higher decreased in $\mathrm{OC}$ and a slight increased in $\% \mathrm{TN}$; Xulux-Tolosa et al. (2003) found that the OC/N ratio decreased during the process of degradation of plant materials; Chen et al. (2003) also found that OC/N ratios decreased during $\mathrm{OM}$ decomposition of plant and soil residues.

\subsection{Rate constant for OM degradation}

Quantitative interpretation of the reactivity of $\mathrm{OM}$ was provided by the rate constant of OM degradation. Determination of the degradation rate constant $(k)$, has been based on OM contents of surface and subsurface sediments:

$k=-\left[\ln \left(C / C_{0}\right)\right] / t$

where $C=$ known concentration at the surface sediment, $C_{0}$ $=$ concentration at the time of deposition at the subsurface sediment, and $t=$ time for deposition (Canuel and Martens, 1996).

Based on the sediment accumulation rate in the upper and lower Loch Creran of 0.5 and $0.2 \mathrm{~cm} \mathrm{yr}^{-1}$ (Loh et al., in preparation), and $0.7 \mathrm{~cm} \mathrm{yr}^{-1}$ in Loch Etive (Howe et al., 2001), the total deposition time beneath the $10 \mathrm{~cm}$ sediment layer in Loch Creran are approximately 20 and 50 years, and for Loch Etive 14.3 years. The degradation rate constant for both lochs ranged from 0.2 to $9.3 \times 10^{-5} \mathrm{~d}^{-1}$ for labile OM, 1.5 to $3.9 \times 10^{-5} \mathrm{~d}^{-1}$ for refractory OM, 1.0 to $4.1 \times 10^{-5} \mathrm{~d}^{-1}$ OC, 2.3 to $7.1 \times 10^{-5} \mathrm{~d}^{-1} \mathrm{TN}$, and 4.1 to $4.6 \times 10^{-5} \mathrm{~d}^{-1}$ lignin (Table 6). For labile OM, $k$ was highest at RE6, followed by LC0, LC3 and RE5; whilst for refractory OM, $k$ was highest at RE6, followed by LC0, LC1, LC5, RE5 and LC3. The higher rate constants at the upper basin of Loch Creran, as well as RE6 compared to RE5, were most probably due to the contribution of relatively fresh terrestrial OM being more susceptible to bacterial action. The " $\mathrm{k}$ " value for refractory OM was higher at LC5 compared to the locations at the upper Loch Creran. This, as well as the rate constant for lignin which increased further down the loch, is most likely related to the role of bioturbation, introducing oxygen to subsurface sediments. The higher degradation rate constant for $\mathrm{OC}$ and $\mathrm{TN}$ in $\mathrm{LC} 1$ compared to $\mathrm{LC} 0$ could also be due to the contribution of terrestrial OM, although more data is needed to enable more detail interpretation.

\section{Conclusions}

Lignin studies indicate that rivers provide an important source of land-derived carbon to Loch Creran and Loch Etive. Non-woody angiosperm tissues predominate in these two Scottish sea lochs. Although woody plants such as beech, birch and oak are found in abundance around both lochs, these non-woody tissues are indicative of the associated mass of leaf material. The observed decrease in lignin, total OM and OC from the head through the lochs seawards, along with significant correlations among these parameters (regression analyses: $p<0.05$ ), indicate that terrestrial material contributes significantly to the sedimentary $\mathrm{OM}$ and carbon inventories. The offshore decreases in these parameters further indicate the importance of rivers in contributing terrestrial $\mathrm{OM}$ to the lochs and that sedimentation of material occurs during transportation along the lochs.

Lignin is a highly complex compound which is largely refractory to biodegradation. In aquatic environments lignin biodegradation is even more problematic, as water is typically less well oxygenated than surface soils. As a result, published studies have reported no lignin degradation occurring in natural waters. As lignin is closely related to the total $\mathrm{OM}$ and $\mathrm{OC}$, however, the overall decrease of oxygen uptake rate through the lochs suggests that terrestrial OM does fuel biogeochemical cycling in these systems.

Oxygen uptake rate and $\mathrm{OC} / \mathrm{N}$ ratio, combined with $R p$ index, have been used successfully to indicate the degree of freshness, or biodegradability, of the sedimentary OM. Sediments near to riverine inputs have higher oxygen uptake rates, indicating higher biodegradability of the sediment $\mathrm{OM}$. In these two lochs, terrestrial compounds constitute a significant fraction of the $\mathrm{O}$. Lower $R p$ values indicate higher fractions of labile $\mathrm{OM}$, which also indicates the presence 
of fresher materials, more susceptible to degradation. Sediments near to riverine inputs also have lower $R p$ values. Finally, we were able to relate the biodegradation of sedimentary OM to molar OC/N ratios. In this work, the study of lignin together with oxygen uptake rate, molar $\mathrm{OC} / \mathrm{N}$ ratio and $R p$ index has shown that these parameters can be used as simple proxies to determine the biodegradability of sedimentary OM in sea loch systems; hence the hypothesis of the study is accepted.

Acknowledgements. We are extremely grateful to D. MacAlpine and S. Douglas of the RV Seol Mara, K. Black and H. Orr for the help with GC analysis, T. Brand for the help with carbon and nitrogen analyses, K. Davidson for carbon isotope determination, S. J. Gontarek for the map, and to everyone at Dunstaffnage Marine Laboratory who has given much useful advice. We are very grateful to the anonymous referees for the detailed comments which improved and strengthened this manuscript greatly.

Edited by: H. H. G. Savenije

\section{References}

Accornero, A., Picon, P., de Bovee, F., Charriere, B., and Buscail, R.: Organic carbon budget at the sediment-water interface on the Gulf of Lions continental margin, Cont. Shelf Res., 23, 79-92, 2003.

Alexander M.: Biodegradation and Bioremediation, 2nd Ed., Academic Press, 453 pp., 1999.

Bashkin V. N.: Modern Biogeochemistry, Kluwer Academic Publishers, 561 pp., 2002.

Benner, R., Fogel, M. L., and Sprague, E. K.: Diagenesis of belowground biomass of Spartina alterniflora in salt-marsh sediments, Limnol. Oceanogr., 36(7), 1358-1374, 1991.

Berg, B., Muller, M., and Wessen, B.: Decomposition of red clover (trifolium pratense) roots, Soil Biol. Biochem., 19(5), 589-593, 1987.

Bianchi, T. S. and Argyrou, M. E.: Temporal and spatial dynamics of particulate organic carbon in the Lake Pontchartrain Estruary, Southeast Lousiania, U.S.A. Estuarine, Coastal and Shelf Science 45, 557-569, 1997.

Bianchi, T. S., Mitra, S., and McKee, B. A.: Sources of terrestriallyderived organic carbon in lower Mississippi River and Louisiana shelf sediments: implications for differential sedimentation and transport at the coastal margin, Mar. Chem., 77, 211-223, 2002.

Boom, A., Mora, G., Cleef, A. M., and Hooghiemstra, H.: High altitude $\mathrm{C} 4$ grasslands in the northern Andes: relicts from glacial conditions?, Rev. Palaeobot. Palyno., 115, 147-160, 2001.

Boutton, T. W.: Stable carbon isotope ratios of natural materials: I. Sample preparation and mass spectrometric analysis, in: Carbon Isotope Techniques, edited by: Coleman, D. C. and Fry, B., Academic Press, 155-171, 1991.

Cerling, T. E., Wang, Y., and Quade, J.: Expansion of C4 ecosystems as an indicator of global ecological change in the late Miocene, Nature, 361, 344-345, 1993.

Chen, X., Cabrera, M. L., Zhang, L., Shi, Y., and Shen, S. M.: Long-term decomposition of organic materials with different car- bon/nitrogen ratios, Commun. Soil Sci. Plan., 34(1,2), 41-54, 2003.

Christman, R. F. and Oglesby, R. T.: Microbiological Degradation and the Formation of Humus, in: Lignins Occurrence, Formation, Structure and Reactions, edited by: Sarkanen, K. V. and Ludwig, C. H., Wiley-Interscience, 769-795, 1971.

Craib, J. S.: A sampler for taking short undisturbed marine cores, Journal du Coneid, Conseid permanent international de exploration de la Mer 30, 34-39, 1965

Degens, E. T.: Biogeochemistry of stable carbon isotope, in: Organic Geochemistry. Methods and Results, edited by: Eglinton, G. and Murphy, M. T. J., Springer-Verlag, 304-329, 1969.

Edwards, A. and Edelsten, D. J.: Deep water renewal of Loch Etive: a three basin Scottish fjord, Estuar. Coast. Mar. Sci., 5, 575-595, 1977.

Edwards, A. and Grantham, B. E.: Inorganic nutrient regeneration in Loch Etive bottom water, in: The Role of Freshwater Outflow in Coastal Marine Ecosystem, NATO ASI Series G: Ecological Sciences, Vol. 7, edited by: Skreslet, S., Springer-Verlag, 195204, 1986.

Edwards, A. and Sharples, F.: Scottish sea lochs: a catalogue, Scottish Marine Biological Association/Nature Conservancy Council, 250 pp., 1986.

Edwards, A. and Trusdale, V. W.: Regeneration of inorganic iodine species in Loch Etive, a natural leaky incubator, Estuar. Coast. Shelf S., 45, 357-366, 1997.

Elsgaard, L. and Jorgensen, B. B.: Anoxic transformations of radiolabeled hydrogen sulfide in marine and freshwater sediments, Geochimica et Cosmochima Acta, 56, 2425-2435, 1992.

Eriksson, K.-E. L., Blanchette, R. A., and Ander, P.: Microbial and Enzymatic Degradation of Wood and Wood Components, Springer-Verlag, 407 pp., 1990.

Ertel, J. R., Hedges, J. I., Devol, A. H., Richey, J. E., and Ribeiro, M. De N. G.: Dissolved humic substances of the Amazon River system, Limnol. Oceanogr., 31, 739-754, 1986.

Gage, J.: A preliminary survey of the benthic macrofauna and sediments in Lochs Etive and Creran, sea-lochs along the west coast of Scotland, J. Mar. Biol. Assoc. UK, 52, 237-276, 1972.

Gearing, J. N., Gearing, P. J., Rudnick, D. T., Requejo, A. G., and Hutchings, M. J.: Isotopic variability of organic carbon in a phytoplankton-based, temperate estuary, Geochimica et Cosmochimica Acta, 48, 1089-1098, 1984.

Glud, R. N., Gundersen, J. K., Jorgensen, B. B., Revsbech, N. P., and Schultz, H. D.: Diffusive and total oxygen uptake of deepsea sediments in the eastern South Atlantic Ocean: in situ and laboratory measurements, Deep-Sea Res. I, 41(11/12), 17671788, 1994.

Goni, M. A. and Hedges, J. I.: Lignin dimers: Structures, distribution, and potential geochemical applications, Geochimica et Cosmochimica Acta, 56, 4025-4043, 1992.

Goni, M. A. and Hedges, J. I.: Sources and reactivities of marinederived $\mathrm{OM}$ in coastal sediments as determined by alkaline $\mathrm{CuO}$ oxidation, Geochimica et Cosmochimica Acta, 59(14), 29652981, 1995.

Goni, M. A., Ruttenberg, K. C., and Eglinton, T. I.: Sources and distribution of terrigenous organic carbon to surface sediments in the Gulf of Mexico, Nature, 339, 275-278, 1997.

Goni, M. A., Ruttenberg, K. C., and Eglinton T. I.: A reassessment of the sources and importance of land-derived OM in surface sed- 
iments from the Gulf of Mexico, Geochimica et Cosmochimica Acta, 62(18), 3055-3075, 1998.

Goni, M. A. and Thomas, K. A.: Sources and transformation of organic matter in surface soils and sediments from a tidal estuary, Estuaries, 23(4), 548-564, 2000.

Goni, M. A., Yunker, M. B., Macdonald, R. W., and Eglinton, T. I.: Distribution and sources of organic biomarkers in arctic sediments from the Mackenzie River and Beaufort Shelf, Mar. Chem., 71, 23-51, 2000.

Gordon, E. S. and Goni, M. A.: Sources and distribution of terrigenous organic matter delivered by the Atchafalaya River to sediments in the northern Gulf of Mexico, Geochimica et Cosmochimica Acta, 67(13), 2359-2375, 2003.

Grant, J. and Hargrave, B. T.: Benthic metabolism and the quality of sediment organic carbon, Biological Oceanography, 4(3), 243264, 1987.

Hamilton, S. E. and Hedges, J. I.: The comparative geochemistries of lignins and carbohydrates in an anoxic fjord, Geochimica et Cosmochimica Acta, 52, 129-142, 1988.

Hansen, H. P.: Determination of oxygen, in: Methods of Seawater Analysis, 3rd Ed., edited by: Grasshoff, K., Kremling, K., and Ehrhardt, M., Wiley-VCH, 75-89, 1999.

Hedges, J. I. and Parker, P. L.: Land-derived organic matter in surface sediments from the Gulf of Mexico, Geochimica et Cosmochimica Acta, 40, 1019-1029, 1976.

Hedges, J. I. and Mann, D. C.: The characterization of plant tissues by their lignin oxidation products, Geochimica et Cosmochimica Acta, 43, 1803-1807, 1979a.

Hedges, J. I. and Mann, D. C.: The lignin geochemistry of marine sediments from the southern Washington coast, Geochimica et Cosmochimica Acta, 43, 1809-1818, 1979b.

Hedges, J. I. and Ertel, J. R.: Characterization of lignin by gas capillary chromatography of cupric oxide oxidation products, Anal. Chem., 54, 174-178, 1982.

Hedges, J. I., Ertel, J. R., and Leopold, E. B.: Lignin geochemistry of a Late Quaternary sediment core from Lake Washington, Geochimica et Cosmochimica Acta, 46, 1869-1877, 1982.

Hedges, J. I., Clark, W. A., Quay, P. D., Richey, J. E., Devol, A. H., and Santos, U. M.: Compositions and fluxes of particulate organic material in the Amazon River, Limnol. Oceanogr., 31(4), 717-738, 1986

Hedges, J. I. and Oades, J. M.: Comparative organic geochemistries of soils and marine sediments, Org. Geochem., 27(7/8), 319-361, 1997.

Henrichs, S. M.: Early diagenesis of organic matter in marine sediments: progress and perplexity, Mar. Chem., 39, 119-149, 1992.

Hirota, J. and Szyper, J. P.: Separation of total particulate carbon into inorganic and organic components, Limnol. Oceanogr., 20, 896-900, 1975.

Howe, J. A., Overnell, J., Inall, M. E., and Wilby, A. D.: A side-scan sonar image of a glacially-overdeepened sea loch, upper Loch Etive, Argyll, Scot. J. Geol., 37(1), 3-10, 2001.

Hurst, H. M. and Burges, N. A.: Lignin and humic acids, in: Soil Biochemistry, edited by: McLaren, A. D. and Peterson, G. H., Marcel Dekker, 260-317, 1967.

Ishiwatari, R. and Uzaki, M.: Diagenetic changes of lignin compounds in a more than 0.6 million-year-old lacustrine sediment (Lake Biwa, Japan), Geochimica et Cosmochimica Acta, 51, 321-328, 1987
Kristensen, E. and Andersen, F. Ø.: Determination of organic carbon in marine sediments: a comparison of two CHN-analyzer methods, J. Exp. Mar. Biol. Ecol., 109, 15-23, 1987.

Kristensen, E.: Characterization of biogenic organic matter by stepwise thermogravimetry (STG), Biogeochemistry, 9, 135-159, 1990.

Leo, R. F. and Barghoorn, E. S.: Phenolic aldehydes: generation from fossil woods and carbonaceous sediments by oxidative degradation, Science, 168, 582-584, 1970.

Liss, P. S., Billen, G., Duce, R. A., Gordeev, V. V., Martin, J.-M., McCave, I. N., Meincke, J., Milliman, J. D., Sicre, M.-A., Spitzy, A., and Windom, H. L.: Group report: what regulates boundary fluxes at ocean margins?, in: Dahlem Workshop Reports, Ocean Margin Processes in Global Change. Physical, Chemical, and Earth Sciences Research Report 9, edited by: Mantoura, R. F. C., Martin, J.-M., and Wollast, R., John Wiley and Sons, 111126, 1991.

Loh, P. S., Reeves, A. D., Overnell, J., Harvey, S. M., and Miller, A. E. J.: Assessment of terrigenous organic carbon input to the total organic carbon in sediments from Scottish transitional waters (sea lochs): methodology and preliminary results, Hydrol. Earth Syst. Sci., 6, 959-970, 2002, http://www.hydrol-earth-syst-sci.net/6/959/2002/.

Loh, P. S., Reeves, A. D., Harvey, S. M., Overnell, J., and Miller, A. E. J.: The fate of terrestrial organic matter in two Scottish sea lochs, Estuar. Coast. Shelf S., 76, 566-579, 2008.

Louchouarn, P., Lucotte, M., Canuel, R., Gagne, J.-P., and Richard L.-P.: Sources and early diagenesis of lignin and bulk organic matter in the sediments of the Lower St. Lawrence Estuary and the Saguenay Fjord, Mar. Chem., 58, 3-26, 1997.

Meyers, P. A.: Organic geochemical proxies of paleoceanographic, paleolimnologic, and paleoclimatic processes, Org. Geochem., 27(5/6), 213-250, 1997.

Milliman. J. D.: Flux and fate of fluvial sediment and water in coastal seas. in: Dahlem Workshop Reports, Ocean Margin Processes in Global Change, Physical, Chemical, and Earth Sciences Research Report 9, edited by: Mantoura, R. F. C., Martin, J.-M., and Wollast, R., John Wiley and Sons, 69-89, 1991.

Miltner, A. and Emeis, K.-C.: Origin and transport of terrestrial organic matter from the Oder lagoon to the Arkona Basin, Southern Baltic Sea, Org. Geochem., 31, 57-66, 2000.

Miltner, A. and Emeis, K.-C.: Terrestrial organic matter in surface sediments of the Baltic Sea, Northwest Europe, as determined by $\mathrm{CuO}$ oxidation, Geochimica et Cosmochimica Acta, 65(8), 1285-1299, 2001.

Mitra, S., Bianchi, T. A., Guo, L., and Santschi, P. H.: Terrestrially derived dissolved organic matter in the Chesapeake Bay and the Middle Atlantic Bight, Geochimica et Cosmochimica Acta, 64(20), 3547-3557, 2000.

Mook, D. H. and Hoskin, C. M.: Organic determination by ignition: caution advised, Estuar. Coast. Shelf S., 15, 697-699, 1982.

Onstad, G. D., Canfield, D. E., Quay, P. D., and Hedges, J. I.: Sources of particulate organic matter in rivers from the continental USA: Lignin phenol and stable carbon isotope compositions, Geochimica et Cosmochimica Acta, 64(20), 3539-3546, 2000.

Overnell, J., Harvey, S. M., and Parkes, R. J.: A biogeochemical comparison of sea loch sediments. Manganese and iron contents, sulphate reduction and oxygen uptake rate, Oceanol. Acta, 19(1), 41-55, 1995. 
Overnell, J. and Young, S.: Sedimentation and carbon flux in a Scottish Sea Loch, Loch Linnhe. Estuarine, Coast. Shelf Sci., 41, 361-376, 1995.

Parkes, R. J. and Buckingham, W. J.: The flow of organic carbon through aerobic respiration and sulphate-reduction in inshore marine sediments, in: Perspective in Microbial Ecology, edited by: Megusar, F. and Gantar, G., Proceedings of the 4th International Symposium on Microbial Ecology, 617-624, 1986.

Parsons, T. R., Takahashi, M., and Hargrave, B.: Biological Oceanographic Processes, Second Edition. Pergamon Press, 332 pp., 1977.

Pocklington, R. and MacGregor, C. D.: The determination of lignin in marine sediments and particulate form in seawater, Int. J. Environ. An. Ch., 3, 81-93, 1973.

Pocklington, R.: Terrigenous organic matter in surface sediments from the Gulf of St. Lawrence, J. Fish. Res. Board Can., 33(1), 93-97, 1976.

Poole, C. F.: Recent advances in the silylation of organic compounds for gas chromatography, in: Handbook of Derivatives for Chromatography, edited by: Blau, K. and King G. S., Heyden, 152-200, 1979.

Prahl, F. G., Ertel, J. R., Goni, M. A., Sparrow, M. A., and Eversmeyer, B.: Terrestrial organic carbon contributions to sediments on the Washington margin, Geochimica et Cosmochimica Acta, 58(14), 3035-3048, 1994.

Readman, J. W., Mantoura, R. F. C., Llewellyn, C. A., Preston, M. R., and Reeves, A. D.: The use of pollutant and biogenic markers as source discriminants of organic inputs to estuarine sediments, Int. J. Environ. An. Ch., 27, 29-54, 1986.

Requejo, A. G., Brown, J. S., and Boehm, P. D.: Lignin geochemistry of sediments from the Narragansett Bay Estuary, Geochimica et Cosmochimica Acta, 50, 2707-2717, 1986.

Rowe, G. T., Boland, G. S., Phoel, W. C., and Biscaye, P. E.: Deepsea floor respiration as an indication of lateral input of biogenic detritus from continental margins, Deep-Sea Res. II, 41(2/3), 657-668, 1994.

Ruttenberg, K. C. and Goni, M. A.: Phosphorus distribution, C:N:P ratios, and $\delta^{13} \mathrm{C}_{o c}$ in arctic, temperate, and tropical coastal sediments: tools for characterizing bulk sedimentary organic matter, Mar. Geol., 139, 123-145, 1997.

Santos, V., Billet, D. S. M., Rice, A. L., and Wolff, G. A.: Organic matter in deep-sea sediments from the Porcupine Abyssal Plain in the north-east Atlantic Ocean. I-Lipids, Deep Sea Res. I, 41(56), 787-819, 1994.
Sarkanen, K. V. and Ludwig, C. H. (Eds.): Lignin Occurrence, Formation, Structure and Reactions, Wiley-Interscience, 916 pp., 1971.

Skoog, D. A. West, D. M., and Holler, F. J.: Fundamentals of Analytical Chemistry, seventh edition, Sounders College Publishing, 870 pp., 1996.

Sutherland, R. A.: Loss-on-ignition estimates of organic matter and relationships to organic carbon in fluvial bed sediments, Hydrobiologia, 389, 153-167, 1998.

Waksman, S. A. and Tenney, F. G.: The composition of natural organic materials and their decomposition in the soil: II. Influence of age of plant upon the rapidity and nature of its decomposition - rye plants, Soil Sci., 24(5), 317-333, 1927.

Ward, G. M., Ward, A. K., Dahm, C. N., and Aumen, N. G.: Origin and formation of organic and inorganic particles in aquatic systems, in: The Biology of Particles in Aquatic Systems, 2nd Ed., Lewis Publishers, 45-73, 1994

Wassman, P.: Sedimentation and benthic mineralization of organic detritus in a Norwegian fjord, Mar. Biol., 83, 83-94, 1984.

Westrich, J. T. and Berner, R. A.: The role of sedimentary organic matter in bacterial sulfate reduction: the $\mathrm{G}$ model tested, Limnol. Oceanogr., 29(2), 236-249, 1984.

Wilson, J. O., Valiela, I., and Swain, T.: Sources and concentrations of vascular plant material in sediments of Buzzards Bay, Massachusetts, USA, Mar. Biol., 90, 129-137, 1985.

Wood, B. J. B., Tett, P. B., and Edwards, A.: An introduction to the phytoplankton, primary production and relevant hydrography of Loch Etive, J. Ecol., 61, 569-585, 1973.

Xuluc-Tolosa, F. J., Vester, H. F. M., Ramirez-Marcial, N., Castellanos-Albares, J., and Lawrence, D.: Leaf litter decomposition of tree species in three successional phases of tropical dry secondary forest in Campeche, Mexico, Forest Ecol. Manag., 174, 401-412, 2003.

Zeikus, J. G.: Fate of lignin and related aromatic substrates in anaerobic environments, in: Lignin Biodegradation: Microbiology, Chemistry, and Potential Applications, Vol. I, edited by: Kent, T. K., Higuchi, T., and Chang Hou-min, CRC Press, 101-109, 1980.

Zimmerman, A. R. and Canuel, E. A.: Bulk organic matter and lipid biomarker composition of Chesapeake Bay surficial sediments as indicators of environmental processes, Estuar. Coast. Shelf S., 53, 319-341, 2001. 